\title{
THE CHARACTERISTICS OF THE THIRD SECTOR IN UKRAINE. INCREASES AND DECREASES IN THE ACTIVITY OF PARTICULAR ORGANIZATIONS AND THE POLICY OF THE RULING ELITE
}

\author{
Kamila Pytlik
}

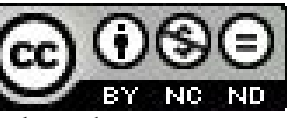

Faculty of Philology and History, Pomeranian University in Słupsk, ul. Arciszewskiego 22a, 76-200 Słupsk, Poland

E-mail address: kamila-pytlik@wp.pl

\begin{abstract}
The main subject of this article is the activity of non-governmental organizations in Ukraine and their role in the life democratization. The article includes methods of financing non-governmental organizations and the influence of domestic and foreign subsidies for their work. Moreover, it raises a question about ethical behaviour of people, that finance these organizations and reveals the political aspects of the decisions which were made.

It depicts the development dynamics of NGOs during several years. Furthermore, it emphasizes the increase of activity of all members of the NGOs during the Orange Revolution and the stagnation caused by the political crisis in 2007. This work indicates what is the stimulus for the development of Ukrainian NGOs.

Keywords: NGOs, development, democratization, the Orange Revolution, political crises, moral principles

Disturbing events in the Ukraine, which have taken place in recent times, are a clear sign of a threat to the democratization process of the country as well as to non-governmental organizations. Their activity is a particularly important contribution to the promotion of ideas of democracy, freedom and signals the protection of human rights. Non-governmental organizations are not subordinate to the governmental authority or self-government. The purpose of these organizations is not profit-making, but the common interest of society. They arise as business institutions - on the initiative of individuals, but as public authorities - acting in the public interest. Such examples are: social organizations, philanthropic foundations, associations, voluntary welfare organizations and carrying out relief actions. This is only an outline that can organize society. Ukrainian society, which is mentioned in the concept of the Third Sector, understands these mainly philanthropic foundations and social organizations. The dynamics of change occurring in Ukrainian society depends on the political situation, as confirmed by the events of 2000, 2004 and later. Changes that occur in the mentality of society, the attitudes of businessmen articulating their rights are slow and very limited.
\end{abstract}




\section{THE HISTORICAL ASPECT AND THE ROOTS OF IDENTITY IN SHAPING THE POLICY AND SOCIAL RESPONSIBILITY}

We must remember that in shaping policy and public awareness the historical issues were important. The disintegration of the Soviet Union gave new opportunities for social, political and economic development, but not all countries were able to take advantage of these opportunities. Many obstacles arose in the process of development. Some introduced partial reforms and the importance of civil society and its role was marginalized (Kolybashkina, 2004, pp.5-6).

In 1992 the Law of Ukraine on Civic Associations was established. It was a crucial moment for NGOs, which resulted in the development of this sector. Bearing in mind the historical context we have to remember the differences of history in the eastern and western parts of the Ukraine. The eastern part of the Ukraine was closely tied with the Soviet Union. This part of the country's population assimilated an ethnic Russian population. Hence, the population of the eastern and southern parts of the Ukraine uses the Russian language more often than people in western part of the country. The different historical past entails a different mentality and consciousness of society. In the case of the east it was the dependence on the Tsarist regime. By contrast, the western part was previously subordinate to the Austrian-Hungarian Empire and the inter war Poland, which gave to the communities more autonomy than in the Soviet Union. Political activity was allowed, which led to the emergence of a social responsibility. Civic nationalism has played a very important role in social mobilization during the Orange Revolution. There should also be some focus on religious issues. The Russian Orthodox Church was anti-western, anti- European, and this attitude was xenophobic in nature. The Ukrainian Greek-Catholic Church supported Viktor Yushchenko in all elections held in 2004, the faithful of the church have been coupled with ethnic nationalism. In addition, the Ukrainian Orthodox Church supported integration with Europe and the democratization of the Ukraine. We should remember that ethnic identity tied with nationalism guarantees the popularization of democratic values. Support given by the Church Autocephalous was due to historical reasons, the church was smothered by Russians, but votes for V. Yushchenko meant for them independence from the Moscow Patriarchate (Kuzio., 2010, pp. 285-287).

The indicated points of view reveal some dichotomies caused by historical heritage. We can observe it in the example of civil society and policy. One of the practices taken from Soviet reality is formal legitimization of power through the use and support of various institutions. Of course these institutions and campaigns supported by the authorities are also founded by the government, which will be discussed later. There is no denying that the authorities have an influence on their functioning and proclaimed views. These are remnants of the Soviet system. Separately, in turn, developing civic movements have set themselves the goal of protecting human rights (Tyszczenko, \& Bakalczuk, 2012, pp. 235-236). 


\section{THE BEGINNINGS OF DEMOCRATIZATION IN THE COUNTRY}

In the late 80 s a group was created, whose aim was to rebuild the country and culture. Former political prisoners and dissidents formed the Ukrainian Popular Movement for Restructuring (Rukh). Rukh began to work in Lviv and later expanded its activities to Kyiv and central Ukraine. In December 1991 Leonid Kravchuk won the presidential election with the Rukh leader - Vyacheslav Chornovil. The authoritarian governments remained a landmark of the Orange Revolution (Tyszczenko, \& Bakalczuk, 2012, p. 288). These were the first signs of social awakening, but as time has shown they were too weak to throw off the yoke of Russian power.

One of the determinants of the democratization level of the country was the activities of NGOs, as they represent the will of the people. The question is: What should the EU do to encourage the Ukraine to follow Europe without looking back? First of all, the EU promotes the democratization of the country, not only by offering economic aid and profit from favorable international agreements, mainly structural and legal changes, but without the cooperation of the leaders of NGOs and the authorities the promotion of democratic values is undermined. According to a study conducted in 2003 only $22 \%$ of the respondents in the Ukraine considered their country to be a democracy, this result was 8\% lower than in 2001 (Kubicek, 2005, pp. 270-271).

According to my observation it is not easy to definitively change the direction of policy in the Ukraine, not only taking into account historical reasons. There should also be focus on economic and social issues. The situation of the Ukraine can be described briefly as being between a rock and a hard place. On the one hand there is Russia with its imperial legacy, and on the other hand the European Union, with its standards and law, which is a challenge for the Ukraine. The choice is difficult, especially since changes need time and any inconvenience will be have an impact on the economic situation of the poorest sections of the population. For these and other reasons the Ukraine has sought to maximize both sides, to which the Union could not agree. To understand the specifics of the changes we should go back to the time when the country was ruled by Leonid Kuchma. He promised reforms, but as time has shown, presidential authority has became more and more dominant, apart from the gains in importance of business groups and oligarchs, the reforms were not needed. L. Kuchma and his policy blocked the reform and liberalization of the country. Moreover, in 2000 a tape was disclosed, which compromised the President of the Ukraine. The case concerned a journalist, Heorhiy Gongadze, who criticized government policies and corruption. The journalist was murdered in mysterious circumstances, but the evidence pointed to the participation of the president (Kudelia, 2012, pp. 420-422). Another situation that caused a drop in support for Kuchma was conflict between the president and Prime Minister Viktor Yushchenko, who wanted to revive the economy. His popularity grew, his government policy brought the first economic growth in the Ukraine for 10 years. These events in the political arena led to the mobilization of the opposition movement against Kuchma, Ukraine Without Kuchma, and the activities of the 
non-governmental organization For Truth. It could be said that this was a prelude to the escalation of the will of the people, which suppressed for years sought sanctuary (Kuzio, 2008, pp. 351).

The growth of public awareness and political events led to an increase in the number of non-governmental organizations. In 2000, the number of NGOs was estimated at 28 000, which operated at the level of rural, regional, nationwide or internationally. Of these, 23065 were civil society organizations, and fewer than 5000 were charities. Moreover, about 55\% of these organizations were registered between 1995-2000 (Kolybashkina., p.7). According to statistics from 2006, including divisions of NGOs due to their activity profiles, it is estimated that there were 46682 social organizations, 9590 were charities and 18617 were religious organizations. What is more, according to research conducted by Counterpart Creative Centre, active organizations are those organizations that functioned for at least two years and completed at least 2 projects. The Lviv region and Kyiv stand out in this regard. This reflects the intensive development and the involvement of members of these organizations (Latsyba., 2006, pp. 47-48).

Non-governmental organizations devoted much attention to social problems primarily concerned with human rights, the development of culture and education. In addition, attention was focused on the issues of health and environmental protection. However, this did not solve all social problems, and worse was that NGOs were faced with numerous administrative and financial problems, which has been a problem up to now (Kolybashkina, p. 7).

\section{DEMOCRATIC BREAKTHROUGH IN UKRAINE}

Escalation of democratic values undoubtedly occurred before the election in 2004. The reason for this was anticipation and fear of the falsification of the presidential election results. Youths, students and volunteers played a leading role. In March 2004, based on youth organizations and NGOs such as: the Christian-Democratic Youth of Ukraine, the Union of Ukrainian Youth, Zarevo, Young Prosvita, the Association of Law Students and a coalition of NGOs, the "Pora" Freedom House was founded. The Pora campaign focused more than 150 different national, regional and local NGOs. The name of campaign meant "It's Time," so for Ukrainians it was time to say enough to the authoritarian regime, corruption, injustice and nepotism (Demes, \& Forbrig, 2006, pp. 87-88).

The major involvement of young people is explained by the fact that they did not have anything to lose. One of the leaders of Znayu (I know) youth NGO Dmytro Potekhin claimed that the authorities took the strikers' most precious and personal thing, their right to vote. Youth was aware that the fate of their country, their future depended on their actions. Znayu organized actions which had a special message for people: "get out the vote." Special messages for society were also preparing by Pora. The strategy of the organization and methods were similar to Serbia's Otpor and Georgia's Kmara. The main objectives of the Pora campaign were to coordinate and monitor the elections, encouragement to participate in the 
vote and to social responsibility. It was a carefully planned and carried out information and psychological operation (Kuzio, 2006, pp. 366-371). Pora was divided into two parts. One of the wings, "yellow", was led by Vladislav Kaskiv. He also led the Freedom of Choice coalition. "Black" Pora had played a primary role in the 2002 and 2003 protests. The organization focused attention on the removal of Leonid Kuchma and his policies of the state, both Pora wings acted independently, and both of them understood that they had to operate without the use of force. "Yellow" Pora was active in promoting an election without fraud and the members of this wing supported V. Yushchenko by organizing pickets, distributing leaflets and indicated differences between the old regime, which was corrupt, and new pro-democratic attempts for reform. Pora organized many actions which forced people to act, and they were recognized by their slogans: "It's Time to Stand Up," "It's Time to Think", "It's Time to Vote”. Their task was to mobilize the masses of society, and awaken people from their social and political stagnation (Demes, \& Forbrig , pp. 90-92).

After the Orange Revolution the number and the professionalism of institutions involved in advocacy for the benefit of society increased. They encountered many adversities including, among other things, the small number of permanent members and the poor quality of judicial services, where judgments could be bought. These negative traits should also include government policies that disregard the rights of citizens, even if they are legally guaranteed. Therefore, many institutions were involved in advocacy and anti-corruption work, working on legislative changes designed to facilitate the registration and operation of NGOs (Latsyba, 2006, p. 49).

\section{THE EU - UKRAINE RELATIONS}

It is worth mentioning that in 1994 the first foundation was created which allowed the Ukraine to cooperate with the EU. This foundation was called the Partnership and Cooperation Agreement (PCA). It created a structure that facilitated annual summits for both partners. The purpose of the PCA was to promote European - Ukrainian relations and to introduce various standards to the Ukraine, concerning trade, business and other sectors of the economy. However, in the way of this cooperation were a number of obstacles and grievances. In 1998 the president issued a decree "Strategy of Ukraine's Integration in the European Union." In 2000, another decree confirmed the pro-European stance. The authorities agreed to adjust national legislation to EU standards. The vision of accession to the European Union gave a chance to stabilize the economy and the political situation. However, when the president's misdeeds came to light, the agreement ceased being passive. The Russians were still considered to be an important trade partner. A good start does not always mean a good ending, and so it turned in this case. In 2003, Kuchma decided to agree to the request of Russia to reverse the Odessa-Brody oil pipeline for Russia's benefit. It was planned that this oil pipeline would connect the city of Odessa with both Plock and Gdansk in Poland, 
but the worse news was that Ukraine acceded to the "Single Economic Space" in 2003, together with Russia, Belarus and Kazakhstan. This meant strengthening the cooperation with these countries. In the same year, the Ukraine became the first non-Russian head of the Commonwealth of Independent States (CIS) Council of State, which was a blow to cooperation with the EU (Kubicek, 2005, pp. 275-280).

According to opinion polls conducted in 2012 Ukrainian society supports cooperation with the EU more than joining NATO, moreover, the authorities resigned from trying to be a part of NATO. As much as $70 \%$ of the population, according to the study, is opposed to entry into NATO structures. Despite this, Ukraine is trying to reform the defense of the country, the training of military personnel as well as co-operation in the areas of technology and counter-terrorism. It should be noted that Russia was not a passive spectator, the government wanted to increase the scope of cooperation with Kiev, even resuming joint naval exercises (Szczepaniuk, 2013).

\section{NON-GOVERNMENTAL ORGANIZATIONS AND THE SOCIETY}

Research conducted by the Razumkov Center enables one to compare the confidence in non-governmental organizations in the Ukraine at different periods of time. Full trust never exceeded 10\%. The maximum value was $7.9 \%$ in February 2005, after the swearing-in of President V. Yushchenko. Summarizing the results of the study, it should be noted that support for NGOs has always been lower than skepticism and distrust, although the NGOs adopt social goals (http:// www.uceps.org/eng/poll.php?poll_id=81). In turn, another survey in 2008 conducted by the same research center showed the extent to which government activities should be controlled by society. The result should reassure us about the self-consciousness of young people (the respondents were aged 18 years). $23.3 \%$ of them stated that all government action should be controlled by the public, 35\% of respondents said that all areas, with the exception of national security, whilst only $2.8 \%$ of respondents were in favour of the authorities not being checked (http:// www.uceps.org/ukr/poll.php?poll_id=361).

The result of this research indicates that young people are watching the political arena and want to be informed about the activities of the authorities, what is more, it can be concluded that the respondents want to "look at the hands" of authorities, to ensure that there is no abuse. It is also worth noting that we cannot measure the effectiveness of the NGO sector through the prism of state power.

As for the facilities and capabilities of non-governmental organizations, in 2005 $61 \%$ of NGOs had a written strategic plan, and only $39 \%$ of organizations had compiled a list of responsibilities for personnel in this form. An important element of these institutions is gratuities and voluntary work. In 2005, 77\% of NGOs benefited from the help of volunteers performing various actions and campaigns. These figures confirm the small number of permanent members. Another issue, but equally important, is to have an office. From $94 \%$ of the institutions which had their own office $79 \%$ of the respondents said they had computer equipment, and $22 \%$ of these organizations had, in 2005, their own web page (Latsyba, 2006, p.49). 


\section{THE CONSEQUENCES OF THE POLITICAL CRISIS}

The activity of NGOs in the Ukraine depends heavily on the political situation and, in 2007, there was another political crisis. The reason for this was a struggle for political influence. Yushchenko's popularity began to decline, in April the president announced the dissolution of parliament, which justified the violation of the constitution by the ruling party, the Party of Regions. It was only during the May consultation that a date emerged for the next parliamentary elections. During the election, which took place in September, most votes were received by the Party of Regions - 34.37\%. Another result was surprising, Yulia Tymoshenko increased her popularity by $8.42 \%$ as compared to 2006 , when she received only $22.29 \%$, but she was the leader of the party which formed a coalition with the presidential bloc Our Ukraine (Bajor , 2008). It can be seen that the social uprising of the Orange Revolution was the nucleus of the crisis, not only political as mentioned, but also in the activities of NGOs. The act of Law on Civic Associations of the early 90s enshrined the right of association, but provides for a number of limitations to those rights in their creation and operation. First of all, the law condemned religious persecution and persecution based on ethnic origin, and also forbade the violation of territorial integrity. However, most doubt was aroused by ambiguous provisions that permit state authorities to intervene in the structure of the organization. One of the arguments was the suspicion of acting on behalf of foreign countries. Not surprisingly, in 2008, the law was declared by the European Court of Human Rights to be incompatible with international standards (Kaźmierkiewicz, 2012, p. 216).

Unable to introduce large-scale democratic reforms because of divisions within the party, fighting between supporters of President V. Yushchenko and Prime Minister Y. Tymoshenko broke out. Focusing on the political struggle did not allow for effective governance. As a result, in 2010, the community elected V. Yanukovych, a former opponent of V. Yushchenko, as president. On the acquisition of the power, Yanukovych promised to sort out the chaos that had resulted from Yushchenko's presidency. Moreover, the new president promised to reform the country's system and he centralized the authority of the state. It should be noted that these actions had popular support. At first it was proposed to comprehensively reform economic stabilization, and to revitalize the agricultural sector and introduce social sector reform. Y. Tymoshenko supported these strong presidential powers. The Party of Regions changed the constitution, which had been introduced by V. Yushchenko. The president once again began to play an important role (Matuszak, 2013, pp. 9-10).

Returning to a presidential system of governance meant that in 2010 the Ukraine was excluded from the ranks of free nations. This ranking was conducted by an American non-governmental organization, Freedom House. In turn, representatives of the European Union emphasized the decreased level of compliance with human rights and freedoms. Representatives of the organization of citizens claimed that their freedom of assembly was being gradually reduced. Furthermore, this report drew attention to the pressure from the SBU on some social organizations (Tyszczenko, \& Bakalczuk, 2012, pp.241-241). 
Not surprisingly, the international community noticed a regression in social and political development in the Ukraine. According to a study conducted by the Center Razumkov, the president was recognized as being the main source of human rights violations. In February $2008,13.7 \%$ of the people in society voted that the president was a violator of a serious offence, but in March 2009 it was 28.7\% ( http://www.uceps.org/ukr/poll.php?poll_id=204).

\section{THE RELATIONSHIP BETWEEN THE STATE AND THE NGOS}

The Ukrainian authorities did not respect the functioning of NGOs and these organizations were not treated as equal partners. This can be seen on the basis of legal acts. Despite the guarantees contained within the 1992 Act, these standards did not pass examination. Freedom of association was subjected to state control. After the Orange Revolution, there were no legislative changes to facilitate the registration of non-governmental activities. Moreover, in 2005-2007 the authorities committed to enact a new law on public organizations. The particular issue that hampered the implementation of various projects was a ban on the cooperation of individuals and legal entities, which is the usual practice in European countries. Another surprising piece of legislation that emerged was the territorial status of the organization. The organization could only operate where it was established and registered. When representatives of the organization intended to widen its activities, the NGO would have to re-register its activities in another region. Discrimination was in play due to the fact that registration of social organizations and charities lasted for 2 months only, and the registration of economic activity lasted for 5 days only. Moreover, non-governmental organizations could not undertake actions of a commercial nature. All of these legal restrictions hinder significantly the operation of NGOs, this increased the time to start activities of this nature, and without the ability to run their own businesses many of them struggled with financial problems (Latsyba, 2006, pp. 50-51).

In March 2012, the Verkhovna Rada adopted the amended law “On Civic Associations," which simplified the registration procedure and shortened the waiting time for registration to seven days, and made the process free (Tyszczenko, \& Bakalczuk, pp. 240-241). So why should we talk about crisis and stagnation during 2005-2010 in the activity of NGOs? The cause of the crisis was not only the political situation, but also changes in staff. Many leaders of the Orange Revolution took on state or party jobs. This was not a positive situation. The recruiting of new leaders took place in an inept manner. Moreover, after 2005 there were many new initiatives dealing with local problems, which was not an integrating factor. The most important issue was the politicizing pseudo-civic initiatives. It can be said that in a period of stagnation among NGOs, alternatives were lacking. These organizations are now faced with the question of what can they do? They need to either retrain or adapt their activities to the current reality (Kohut, 2012, p. 224).

The decrease in the activity of NGOs is illustrated in statistical data. In 2009, it is estimated there were $4000-5000$ functioning organizations, and in 2010 the 
number was $3000-4000$. It is hard to determine the exact number of these institutions because sometimes they closed down their operations without submitting any formal documents. What is more, the United States Agency for International Development (USAID) assessed the development and stability of the non-governmental sector. After 2004, the level of the Ukraine was set at 3,8 to 7 points, where 7 is the ratio of the lowest standards. (Kaźmierkiewicz P., 2012, p. 219). However, in 2011 the degree decreased to 3,5 (Fundusz Inicjatyw Obywatelskich na lata 2014-2020, 2012, p.20). Despite the decline in the level of development, in last months of 2009 and in 2010 the situation changed. We have seen some recovery in society. Activists claimed to be the third force in the country and they should be united, but they did not create any nationwide efforts at organization. Since 2007, the members of civil society organizations have organized the Civic Congress of Ukraine, on this basis they established the Civic Council of Ukraine. This organization has popularized the idea of an amendment to the Constitution and the establishment of the Constituent Assembly. In 2009, activists organized a civic campaign which was called "the New Citizen". This campaign has united almost 40 civil society organizations, which has created an image of the responsible citizen. These events resulted in the convening of a forum, to which the president was invited. Apart from this interesting non-governmental action the third sector has not organized any actions on a large-scale. There have only been smaller scale actions of a local nature (Kohut,2012, pp. 227-228).

\section{THE FINANCING OF SOCIAL SECTOR}

An important element of the functioning of NGOs is their way of financing, the payment of workers and campaign finance. Also important is a common relationship between NGOs and state authorities.

The policies from the government sector did not favour the positive role and activities of NGOs and this still remains the same. The strategy which was adopted by the government is discriminatory and unstable. There are also threats to NGOs due to the lack of local funding sources and dependence on foreign donors. One of the main sources of financing is direct financial aid. 59\% of private donors financially support budgetary institutions such as schools. Only $36 \%$ support charitable organizations, due to the multiple scandals involving these organizations and the illegal use of donated funds. Added to these financial problems is the unfavorable tax system for donors, which was discouraging (Latsyba, 2006, pp. 52-53). This all means that actions and campaigns are created by bottom-up initiatives of individuals. In 2009, Volodymyr Jakymiv created and directed the association "Family Town". The association organized several festivals with a national character, even though they had no office and the personnel did not receive any salary. What is more, some projects they financed on their own or by taking a loan from a bank. We should ask the question: why does the federal government not provide funds to finance positive action for the regions or state? (Borisow , \& Janowycz , 2012, pp. 253-254). 
The financing of NGOs is essential. In the Ukraine, state funding was about $2-3 \%$, in comparison with European countries, where funding was approximately $30-40 \%$ it looks unfavorable. The lack of attention paid to cooperating with NGOs resulted in inefficient operations (Latsyba, 2006, p. 54). Some part of the grant is awarded behind closed doors, an example being the disability organizations, which received 55.9 million hryvnia from the government in 2011. Organizations supporting veterans and dealing with the maintenance and upkeep of military cemeteries also received grants in this way (Tyszczenko, \& Bakalczuk , 2012, p. 236).

It should be noted that state subsidies are dependent on the activity profile and perception of state power. This means that the state uses NGOs to legitimize their actions. It seems disagreeable when the very laudable aims of activists are co-opted for government use. Sometimes NGOs prefer to refuse state subsidies to operate independently. Discussion in this case focuses on the ethics of government, because the state and legal system is constructed to hamper NGOs' activities.

Attention must also focus on the financing of NGOs by foreign donors. NGOs are intermediaries between society and the authorities, but also the determinant of democratization of the country. It is hard to adapt the semi-authoritarian regime to democratic norms. Many funds have been earmarked by the United States and the European Union. The EU supports the activities of the third sector through the implementation and execution of common programs on issues of migration, human rights and democratization. Now the question is how much money actually goes to NGOs? The local authorities and NGOs do not take part in the consultation process. This system of cooperation does not take into account local specificities. The International Centre for Policy Studies and the International Renaissance Foundation both operate in the Ukraine. They seek to create common goals, but it is difficult in the current situation. Full cooperation requires changes in the national, institutional and legal spheres. The worst thing that happened in the past, with regard to the state's control of NGOs, was the commercialization of the sector by foreign donors. The reason for this was the implementation of projects in accordance with their wishes. (Kaca, 2010).

The decrease in the activities of NGOs after the Orange Revolution was caused by the fact that some donors began to support the state budget in order to introduce institutional changes. The NGOs' situation is more complicated due to the refusal to sign an Association Agreement with the EU. Moreover, in January of this year, the authorities introduced a legal amendment, which concerns the activities of NGOs. According to these new provisions, organizations which receive funding from abroad will be acknowledged as a foreign agents. In addition, any organization that engages in political activities will meet the same fate. Any foreign association must also register as a foreign agent. All financial transactions will have to be documented (http://www.ucipr.kiev.ua/publications/backslidings-in-legislation-on-ngos-in-ukraine/lang/en). 


\section{CONCLUSIONS}

The main goal of this article was to highlight the situation of NGOs in the Ukraine, but also that power as a simulator the activities of the third sector. This is not a good situation, because NGOs should exist regardless of the current system. In recent times, we have been observers of an internal struggle led by many people who have decided to go out on to the streets and take part in protests. The whole process of democratization does not really have a concrete date of commencement. The process of democratization was initiated in the minds of people, and later became a goal on its own. It will be pity if the potential which Ukrainians have in themselves is wasted. A certain duality of Ukrainian society needs to be understood, which is deeply rooted in history, so at the outset I pointed out cultural and religious differences, and those associated with consciousness.

\section{REFERENCES}

Backslidings in legislation on NGOs in Ukraine. (2014). Retrieved from http://www.ucipr.kiev.ua/ publications/backslidings-in-legislation-on-ngos-in-ukraine/lang/en

Bajor P. (2008)., Ukraina po wyborach - koniec czy kontynuacja kryzysu?[Ukraine after the elections - the end or the continuation of a crisis] Retrieved from http://www.inp.uj.edu.pl/c/ document_library /get_file?uuid=df33b6a3-fb2b-4c95-a229-23021b93f4ba\&groupId=3905854

Borisow J., \& Janowych A. (2012). Oddolne inicjatywy lokalne, jako alternatywa dla sektora NGO w Ukrainie [Local grassroots initiatives as an alternative for the NGO sector in Ukraine].In: Raport o stanie kultury i NGO w Ukrainie [A Report on the Condition of Culture and NGOs in Ukraine], (pp. 249-258) Lublin: Episteme.

Demes P., \& Forbrig J. (2006). Pora- "It's Time” for Democracy In Ukraine. In: Aslund A., \& McFaul M. (Eds.), Revolution in Orange. The Origins of Ukraine's Democratic Breakthrough, Washington, DC: Carnegie Endowment for International Peace

Fundusz Inicjatyw Obywatelskich na lata 2014-2020 [Civic Initiatives Fund for 2014-2020]. (2012). Retrieved from http://www.pozytek.gov.pl/files/pozytek/PO\%20FIO/FIO\%202014_2020_24_10_2012.pdf

http:/ / www.ucipr.kiev.ua/ publications/backslidings-in-legislation-on-ngos-in-ukraine/lang/en. Retrieved. February 14, 2014.

Kaca E.,(2010). O nas bez nas" - Unia Europejska wobec sektora pozarzadowego w Europie Wschodniej ["About Us Without Us" - The European Union and non-governmental sector in Eastern Europe]. Retrieved from www.new.org.pl/83,post.html.

Kaźmierkiewicz P. (2012). Stan ukraińskiego społeczeństwa obywatelskiego - próba diagnozy [The Condition of Ukrainian Civil Society - an attempt at diagnosis ].In: Raport o stanie kultury i NGO w Ukrainie [A Report on the Condition of Culture and NGOs in Ukraine], Lublin: Episteme.

Kohut A. (2012). Ukraińskie spoteczeństwo obywatelskie 2012 - w poszukiwaniach alternatywy [The Ukrainian Civil Society of 2012 - in serach of an alternative]. In: Raport o stanie kultury i NGO w Ukrainie [A Report on the Condition of Culture and NGOs in Ukraine], Lublin: Episteme.

Kolybashkina, N., (n.d.)Reaching the equilibrium? State - third sector partnership in social services provisions: a case study analysis of current policies in England and Ukraine. Paper prepared for 6th ISTR international conference: Contesting Citizenship and Civil Society in a Divided World, Toronto, 11-14.07.2004. Retired February 4, 2014, from http://c.ymcdn.com/sites/www.istr.org/resource/resmgr/working_papers_toronto/kolybashkina.nina.pdf.

Kubicek P.(2005). The European Union and democratization in Ukraine. Communist and Post-Communist Studies, 38, (pp. 269-292).

Kudelia S. (2012). The sources of continuity and change of Ukraine's incomplete state. Communist and Post-Communist Studies, 45, (pp. 417-428).

Kuzio, T.(2010). Nationalism, identity and civil society in Ukraine: Understanding the Orange Revolution. Communist and Post-Communist Studies 43, (pp. 285-296). 
Kuzio T. (2008). Ukraine: Muddling Along. In: S. L. Wolchik . \& J. L. Curry . (Eds.). Central and East European Politics: From Communism to Democracy, Lanham

Kuzio T.(2006). Civil society, youth and societal mobilization in democratic revolutions, Communist and Post- Communist Studies, 39, (pp. 365-386).

Latsyba M.(2006). Polityka państwa i stan rozwoju społeczeństwa obywatelskiego na Ukrainie [The policy and the condition of civil society in Ukraine]. Trzeci Sektor, 8, (pp. 47-60).

Matuszak S., \& Sarna A. (2013). Od stabilizacji do stagnacji. Próby reform Wiktora Janukowycza [From stabilisation to stagnation. Victor Yanukovych's Reforms], Retired from http://www.osw.waw. pl/sites/default/files/pw_32_pl_net.pdf.

Sociological poll. Retrieved February 7, 2014 from http://www.uceps.org/eng/poll.php?poll_id=81.

Sociological poll. Retrieved February 8, 2014 from http://www.uceps.org/ukr/poll.php?poll_id=204.

Sociological poll. Retrieved February 8, 2014 from http://www.uceps.org/ukr/poll.php?poll_id=361.

Szczepaniuk C. (2002). Wspótpraca Ukrainy z NATO - lepsza niż sie wydaje? [Ukraine's cooperation with NATO - better than it sounds? ], Retrieved from http:/ / eastbook.eu/2013/11/country/ukraine/wsp\%C3\%B3\%C5\%82praca-ukrainy-z-nato-\%E2\%80\%93-lepsza-ni\%C5\%BC-si\%C4\%99wydaje/

Tyszczenko J., \& Bakalczuk W.(2012). Organizacje pozarzadowe a władza: pomiędzy tożsamościa kultura i polityka [Non-governmental organizations and the government: on the borderline of identity, culture and politics]. In: Raport o stanie kultury i NGO w Ukrainie [A Report on the Condition of Culture and NGOs in Ukraine]. Lublin: Episteme. 